\title{
Enhanced Removal of Arsenite from Ground Water by Adsorption onto Heat-Treated Rice Husk
}

\author{
Abdus Samad1, Takumi Fukumoto1, Ahmed H. A. Dabwan², Hideyuki Katsumata1, \\ Tohru Suzuki³ ${ }^{3}$ Mai Furukawa1, Satoshi Kaneco', ${ }^{1,3}$ \\ ${ }^{1}$ Department of Chemistry for Materials, Graduate School of Engineering, Mie University, Mie, Japan \\ ${ }^{2}$ Faculty of Chemical Engineering Technology, Tati University College, Kemaman, Malaysia \\ ${ }^{3}$ Mie Global Environment Center for Education \& Research, Mie University, Mie, Japan \\ Email: kaneco@chem.mie-u.ac.jp
}

Received 12 May 2016; accepted 11 July 2016; published 14 July 2016

Copyright (C) 2016 by authors and Scientific Research Publishing Inc.

This work is licensed under the Creative Commons Attribution International License (CC BY). http://creativecommons.org/licenses/by/4.0/

(c) (i) Open Access

\begin{abstract}
The effect of heat treatment for rice husk was investigated on the removal of arsenite in ground water by the adsorption onto the rice husk surface. The heat treatment was performed at the temperature from $80^{\circ} \mathrm{C}$ to $300^{\circ} \mathrm{C}$ in the closed system under anoxic environment. The continuous adsorption column method was applied for the removal of arsenite. The removal efficiency $(75 \%)$ with rice husk treated at $150^{\circ} \mathrm{C}$ was better compared to those (54\%) obtained with untreated rice husk. Therefore, the heat treatment of rice husk at relatively low temperature was effective for the enhancement of arsenic removal from water. The treatment conditions of As removal from aqueous solution were optimized. The developed treatment technique was applied into the real ground water sample in Bangladesh. The As concentration in sample water after treatment was approximately 18 and $8 \mu \mathrm{g} / \mathrm{L}$, which was below the WHO guideline value of maximum admissible level of arsenic in ground water for Bangladesh (50 $\mu \mathrm{g} / \mathrm{L})$. The developed technique might become a potential avenue for simple and low cost arsenic removal methods.
\end{abstract}

\section{Keywords}

Removal, As, Arsenite, Rice Husk, Heat Treatment

\section{Introduction}

A general problem of recent years is the huge amounts of effluents resulted in aquatic systems (rivers, lakes, sea

How to cite this paper: Samad, A., Fukumoto, T., Dabwan, A.H.A., Katsumata, H., Suzuki, T., Furukawa, M. and Kaneco, S. (2016) Enhanced Removal of Arsenite from Ground Water by Adsorption onto Heat-Treated Rice Husk. Open Journal of Inorganic Non-Metallic Materials, 6, 18-23. http://dx.doi.org/10.4236/ojinm.2016.63004 
etc.) which consisted of toxic metals. Arsenic (As) is among the most hazardous elements existed in effluents. Although both organic and inorganic forms of arsenic exist in natural water, inorganic arsenic occupies the major portion. Predominant species of inorganic arsenic in water are arsenite As(III) and arsenate As(V) [1]. Arsenite is 25 - 60 times more toxic than arsenate [2], and has less efficiency to the surface of various adsorbents compared with $\mathrm{As}(\mathrm{V})$ because $\mathrm{As}(\mathrm{III})$ exists mainly as nonionic $\mathrm{H}_{3} \mathrm{AsO}_{3}$ in natural water with $\mathrm{pH}$ value ranging from weakly acidic to weakly alkaline [3] [4].

A number of treatment techniques such as adsorption, cation exchange, lime softening, reverse osmosis, coagulation and precipitation have been developed for arsenic decontamination. Adsorption has been paid more attention due to its simplicity, cost effectiveness, eco-friendly and availability of wide range of adsorbents [5] [6]. Rice husk (RH) is a well-known low cost adsorbent for removal processes. It contains abundant floristic fiber, protein and functional groups such as carboxyl, hydroxyl and amidogen which make adsorption process possible [7] [8]. The direct use of rice husk for arsenic removal has been reported in the recent studies [5] [9] [10]. However, the low removal efficiency of reported methods limited the practical application. Recent research efforts have been focused on the modification of RH surface in order to improve the arsenic adsorption efficiency. Mondol et al. [11] examined the removal of trivalent arsenic (As(III)) from contaminated water by $\mathrm{CaCl}_{2}$-impregnated rice husk carbon. Agrafioti et al. [12] reported the arsenic removal from water using biochar derived from rice husk. In the study, the removal of only $\mathrm{As}(\mathrm{V})$ was tested, and the maximum adsorption efficiency was $2.59 \mu \mathrm{g} / \mathrm{g}$, which was very poor compared with other conventional techniques. Moreover, relatively high temperature $\left(300^{\circ} \mathrm{C}\right)$ was used for preparing biochar. Therefore, there is little information on the As(III) removal in water with rice husk heated at relatively low temperature.

The present study has dealt mainly with enhanced removal of arsenite from ground water by adsorption onto $\mathrm{RH}$ treated at relatively low temperature.

\section{Experimental}

\subsection{Chemicals}

All Chemicals and reagents used in this work were of analytical-grade purity. Potassium arsenite $\left(\mathrm{KAsO}_{2}\right.$, Wako, Japan) was used for preparing $\mathrm{As}(\mathrm{III})$ stock solution. $\mathrm{NaOH}, \mathrm{KOH}, \mathrm{HCl}, \mathrm{HNO}_{3}$ and $\mathrm{H}_{2} \mathrm{SO}_{4}$ (Nacalai, Japan) were used as chemicals. Ultrapure water was obtained from an ultrapure Advantac RDF260 water system resulting in a resistivity of $>18.0 \mathrm{M} \Omega \cdot \mathrm{cm}$.

\subsection{Preparation of Sorbent Medium}

RH used in this study was obtained from Bangladesh. The chemical composition of RH has been reported as $49.3 \mathrm{wt} \%$ oxygen, $44.6 \mathrm{wt} \%$ carbon and $5.6 \mathrm{wt} \%$ hydrogen (by elemental analysis); $34.4 \mathrm{wt} \%$ cellulose, $29.3 \mathrm{wt} \%$ hemicellulose, $19.2 \mathrm{wt} \%$ lignin and $17.1 \mathrm{wt} \%$ ash (by component analysis); and $59.5 \mathrm{wt} \%$ volatiles, $17.1 \mathrm{wt} \%$ ash and $7.9 \mathrm{wt} \%$ moisture (by proximate analysis) [13]. RH was washed several times with pure water, followed by drying in an oven at $60^{\circ} \mathrm{C}$ for $24 \mathrm{~h}$. Dried rice husk was put in a close steel chamber, and was heated in the oven at a given temperature during 2 hours. The treated $\mathrm{RH}$ was cooled and sieved into five fractions: particle size 710 - $850 \mu \mathrm{m}$ (avg. $780 \mu \mathrm{m}$ ), 600 - $710 \mu \mathrm{m}$ (avg. $655 \mu \mathrm{m}$ ), 425 - $600 \mu \mathrm{m}$ (avg. $510 \mu \mathrm{m}$ ), $355-425 \mu \mathrm{m}$ (avg. $390 \mu \mathrm{m}$ ), and $150-355 \mu \mathrm{m}$ (avg. $250 \mu \mathrm{m})$.

\subsection{Arsenic Adsorption Treatment}

The glass column $(2 \times 30 \mathrm{~cm})$ equipped with a stopper for controlling the treatment rate was used to the As removal. The heat treated RH was packed into the column. After the $\mathrm{pH}$ of the solution was adjusted to desired value with $\mathrm{HCl}$ and $\mathrm{NaOH}$ solutions, the $100 \mathrm{~mL}$ solution was passed through the adsorption column at a given flow rate. The treatment factors including the heat treatment temperature of $\mathrm{RH}\left(80^{\circ} \mathrm{C}-300^{\circ} \mathrm{C}\right)$, adsorbent dosage $(0.5$ - $7 \mathrm{~g})$, average particle size $(250-780 \mu \mathrm{m})$, treatment flow rate $(0.6-20 \mathrm{~mL} / \mathrm{min})$, initial sample concentration (50 - $500 \mu \mathrm{g} / \mathrm{L})$, and $\mathrm{pH}(4-13)$ were evaluated. The treatment flow rates of $0.6,0.8,1.7,3.3,6.7,10$ and $20 \mathrm{~mL} / \mathrm{min}$ corresponded to retention time of $5.3 \mathrm{~min}, 4 \mathrm{~min}, \sim 109 \mathrm{~s}, \sim 58 \mathrm{~s}, \sim 29 \mathrm{~s}, \sim 10 \mathrm{~s}$ and $\sim 6 \mathrm{~s}$, respectively, for $1 \mathrm{~g}$ of heat treated $\mathrm{RH}$. The flow rate was constantly maintained by regulating the stopper valve. The removal experiments were performed at ambient temperature. The number of experiments for the removal of As was three and average value was taken. Concentration of arsenic was determined by graphite furnace atomic 
absorption spectrometer (GFS97, Thermo Electron Corp.) under the following conditions: resonance line, 193.7 $\mathrm{nm}$ (As hollow cathode lamp); pyrolysis temperature, $1200^{\circ} \mathrm{C}(20 \mathrm{~s})$; atomization temperature, $2600^{\circ} \mathrm{C}(3 \mathrm{~s})$; and matrix modifier, nickel nitrate (10 mg/L). The removal (adsorption) efficiency was calculated using the following equation:

$$
\text { Removal (adsorption) efficiency }=\left(\mathrm{C}_{0}-\mathrm{C}_{\mathrm{e}}\right) / \mathrm{C}_{0} \times 100
$$

where $\mathrm{C}_{0}$ and $\mathrm{C}_{\mathrm{e}}$ are the concentration of As in the sample solution before and after treatment, respectively.

\section{Results and Discussion}

\subsection{Effect of Heat-Treated Rice Husk}

The effect of heat treatment for RH on As removal are presented in Figure 1. With untreated RH, the removal efficiency was only $52 \%$. However, the efficiencies with heat treated RH increased to $60 \%-74 \%$. When the thermogravimetry analysis at $<309^{\circ} \mathrm{C}$ was performed for RH, the TG curve presents three mass loss stages in the range of 37 - 118, 118 - 220 and 220 - 309 due to the weight loss of organic constituents and residual $\mathrm{H}_{2} \mathrm{O}$ water [14]. The thermal treatment of RH under poor oxygen atmosphere leaded to the production of black RH ash (carbon). The black RH ash contains larger proportion of carbon than the RH ash produced by other techniques [15]. Heat treated RH may have very high porosity and become good adsorbent for the adsorption of metal [16]. The amorphous carbon with high porosity might be responsible for the increment of As removal efficiency. At $300^{\circ} \mathrm{C}$, RH surface might enrich silica since a part of organic substances gets lost during the heat treatment. The heat treatment at $150^{\circ} \mathrm{C}$ was selected for further investigation.

The influence of particle size of heat treated RH on As removal was investigated. The removal efficiency with average particle size of $790 \mu \mathrm{m}$ was maximum.

\subsection{Effect of Adsorbent Dose}

The effect of adsorbent dose on the As removal with heat treated RH was studied. The As removal efficiency sharply increased with increasing the adsorbent amount from $0.3 \mathrm{~g}(47.9 \%)$ to $1.0 \mathrm{~g}(74.1 \%)$, then the efficiency gradually increased to $91.5 \%$ with the dose up to $3.0 \mathrm{~g}$. The maximum removal efficiency (96.6\%) was obtained with $5.0 \mathrm{~g}$ of dose. The better efficiency with larger dose may be attributed to the availability of more active sites for heat treated RH [17] [18].

\subsection{Effect of Flow Rate and As Concentration}

The influence of flow rate on the As removal with heat treated RH was investigated in the aqueous solution, and

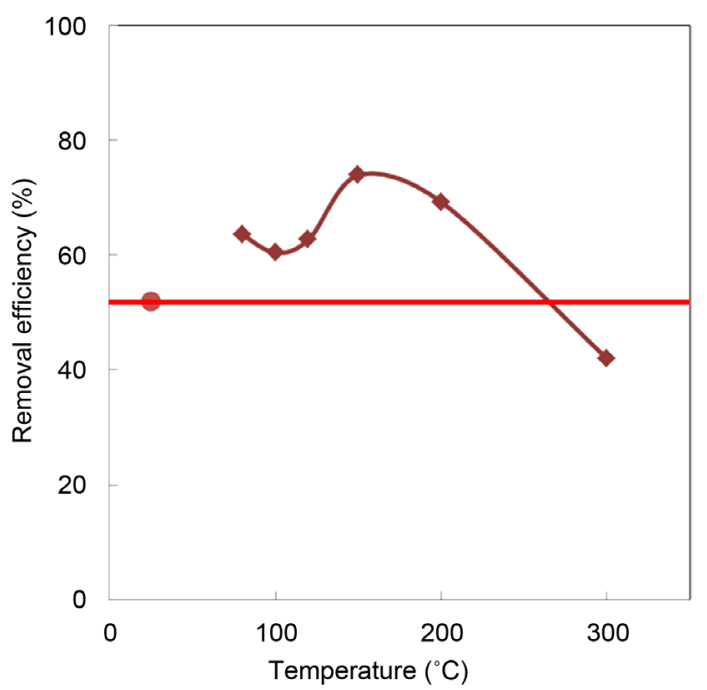

Figure 1. Effect of heat treated rice husk on the removal of As(III) from aqueous solution. As concentration: $100 \mu \mathrm{g} / \mathrm{L}$; sample pH: 6.5; heat treated RH: 1.0 g; particle size: 600 - $850 \mu \mathrm{m}$; flow rate: $1.7 \mathrm{ml} / \mathrm{min}$. 
the optimum flow rate was $6.7 \mathrm{~mL} / \mathrm{min}$. Next, the effect of As concentration on the removal of As using heat treated RH was evaluated. The removal efficiency decreased with the increase in initial As concentration. Therefore, arsenic uptake increased with increasing initial concentration. From the data for the As uptake amount against unit weight of adsorbent $(\mu \mathrm{g} / \mathrm{g})$, arsenic adsorption amount $(\mu \mathrm{g} / \mathrm{g})$ increased with increasing initial As concentration up to $400 \mu \mathrm{g} / \mathrm{L}$. This means it that adsorption capacity of As was $22 \mu \mathrm{g} / \mathrm{g}$ for heat treated RH. The value was better compared with those obtained with untreated RH $(16 \mu \mathrm{g} / \mathrm{g})$.

\subsection{Effect of Sample pH}

The $\mathrm{pH}$ of the aqueous solution is an important factor in the metal adsorption studies, as it affects the dissociation of cation exchange groups on the adsorbent, stability of metal complexes and speciation of metals during reaction [19]. Therefore, the effect of sample $\mathrm{pH}$ on the As removal with heat treated $\mathrm{RH}$ was studied in the $\mathrm{pH}$ range from 4 to 13 . The maximum efficiency was observed at $\mathrm{pH}$ 6.5. The higher removal efficiency at near neutral $\mathrm{pH}$ can be attributed to the lack of electrostatic repulsion between the surface and the neutral As(III) species. The physical adsorption and interaction between the $\mathrm{H}_{3} \mathrm{AsO}_{3}$ species and the heat treated $\mathrm{RH}$ surface might be partly responsible for the removal of As(III). The adsorption process at near neutral $\mathrm{pH}$ may play very significant role in the practical treatment of As-contaminated water.

\subsection{Reaction Mechanism}

Adsorption is a complex process involving several mechanisms which include adsorption (chemisorption), complexation on surface and pores, ion exchange, micro-precipitation and surface adsorption [20]. As(III) adsorption with heat treated RH surface can be attributed to the fact of physisorption and affinity adsorption.

\subsection{Application to Real Water Sample}

The utility of heat treated RH was evaluated for the treatment of As-contaminated groundwater of Bangladesh. The treatment parameters contained the heat treatment temperature $150^{\circ} \mathrm{C}$, average particle size $790 \mu \mathrm{m}$, flow rate 6.7 $\mathrm{mL} / \mathrm{min}$ and adsorbent amount $5.0 \mathrm{~g}$. The results are presented in Table 1. From the present data, the arsenic was successfully removed from practical As-contaminated groundwater. The desorption efficiencies with $100 \mathrm{~mL}$ of 1 $\mathrm{M} \mathrm{KOH}$ were $53 \%$ and $50 \%$.

\section{Conclusion}

The Adsorption of arsenite onto heat-treated rice husk was very effective for the removal of As from ground water. The proposed column treatment system was suitable homemade approaches to arsenite removal in local areas. Direct removal of arsenite can be achieved without first oxidizing arsenite to arsenate, whereas the traditional methods require the oxidation process. Since rice husks are abundant agricultural wastes, they are readily available.

\section{Acknowledgements}

The present research was partly supported by Grant-in-Aid for Scientific Research (C) 15K00602 from the Ministry of Education, Culture, Sports, Science, and Technology of Japan. All experiments were conducted at Mie

Table 1. Removal of As(III) from ground water of Bangladesh.

\begin{tabular}{|c|c|c|}
\hline & Sample 1 & Sample 2 \\
\hline $\mathrm{pH}$ & 6.8 & 6.9 \\
\hline Initial As concentration $(\mu \mathrm{g} / \mathrm{L})$ & 117 & 123 \\
\hline Final concetration $(\mu \mathrm{g} / \mathrm{L})$ & 18 & 8 \\
\hline Removal (\%) & 85 & 94 \\
\hline Desorption (\%) & 53 & 50 \\
\hline
\end{tabular}


University. Any opinions, findings, conclusions or recommendations expressed in this paper are those of the authors and do not necessarily reflect the view of the supporting organizations.

\section{References}

[1] Kumari, P., Sharma, S., Srivastava, S. and Srivastava, M.M. (2005) Arsenic Removal from the Aqueous System Using Plant Biomass: A Bioremedial Approach. Journal of Industrial Microbiology and Biotechnology, 32, 521-526. http://dx.doi.org/10.1007/s10295-005-0042-7

[2] Korte, N.E. and Fernando, Q. (1991) A Review of Arsenic(III) in Groundwater. Critical Reviews in Environmental Control, 21, 1-39. http://dx.doi.org/10.1080/10643389109388408

[3] Lee, H. and Choi, W. (2002) Photocatalytic Oxidation of Arsenite in $\mathrm{TiO}_{2}$ Suspension: Kinetics and Mechanisms. Environmental Science \& Technology, 36, 3872-3878. http://dx.doi.org/10.1021/es0158197

[4] Kim, Y., Kim, C., Choi, I., Rengaraj, S. and Yi, J. (2004) Arsenic Removal Using Mesoporous Alumina Prepared via a Templating Method. Environmental Science \& Technology, 38, 924-931. http://dx.doi.org/10.1021/es0346431

[5] Ranjan, D., Talat, M. and Hasan, S.H. (2009) Rice polish: An Alternative to Conventional Adsorbents for Treating Arsenic Bearing Water by Upflow Column Method. Industrial \& Engineering Chemistry Research, 48, 10180-10185. http://dx.doi.org/10.1021/ie900877p

[6] Srivastava, S., Raj, K.R. and Kardam, A. (2012) Efficient Arsenic Depollution in Water Using Modified Maize Powder. Environmental Chemistry Letters, 11, 47-53. http://dx.doi.org/10.1007/s10311-012-0376-0

[7] Han, R.P., Li, Y.H., Li, H.Q., Wu, Y.J. and Shi, J. (2004) The Elemental Analysis and FT-IR Comparison between MDP and Casting. Spectroscopy \& Spectral Analysis, 24, 185-186.

[8] Chuah, T.G., Jumasiah, A., Azni, I., Katayon, S. and Choong, S.Y.T. (2005) Rice Husk as a Potentially Low-Cost Biosorbent for Heavy Metal and Dye Removal: An Overview. Desalination, 175, 305-316. http://dx.doi.org/10.1016/j.desal.2004.10.014

[9] Amin, M.N., Kaneco, S., Kitagawa, T., Begum, A., Katsumata, H., Suzuki, T. and Ohta, K. (2006) Removal of Arsenic in Aqueous Solutions by Adsorption onto Waste Rice Husk. Industrial \& Engineering Chemistry Research, 45, 81058110. http://dx.doi.org/10.1021/ie060344j

[10] Abbas, M.N. and Abbas, F.S. (2013) Utilization of Iraqi Rice Husk in the Removal of Heavy Metals from Wastewater. Research Journal of Environmental and Earth Sciences, 5, 370-380.

[11] Mondal, P., Majumder, C.B. and Mohanty, B. (2007) Removal of Trivalent Arsenic (As(III)) from Contaminated Water by Calcium Chloride $\left(\mathrm{CaCl}_{2}\right)$-Impregnated Rice Husk Carbon. Industrial \& Engineering Chemistry Research, 46, 2550-2557. http://dx.doi.org/10.1021/ie060702i

[12] Agrafioti, E., Kalderis, D. and Diamadopoulos, E. (2014) Arsenic and Chromium Removal from Water Using Biochars Derived from Rice Husk, Organic Solid Wastes and Sewage Sludge. Journal of Environmental Management, 133, 309-314. http://dx.doi.org/10.1016/j.jenvman.2013.12.007

[13] Williams, P.T. and Nugranad, N. (2000) Comparison of Products from the Pyrolysis and Catalytic Pyrolysis of Rice Husks. Energy, 25, 493-513. http://dx.doi.org/10.1016/S0360-5442(00)00009-8

[14] Xiong, L., Sekiya, E.H., Wada, S. and Saito, K. (2009) Facile Catalytic Combustion of Rice Husk and Burning Temperature Dependence of the Ashes. ACS Applied Materials and Interfaces, 1, 2509-2518. http://dx.doi.org/10.1021/am9004623

[15] Razavi, Z., Mirghaffari, N. and Rezaei, B. (2015) Performance Comparison of Raw and Thermal Modified Rice Husk for De-Contamination of Oil Polluted Water. Clean-Soil, Air, Water, 43, 182-190. http://dx.doi.org/10.1002/clen.201300753

[16] Genieva, S., Turmanova, S., Dimitrov, A., Petkov, P. and Vlaevm, L. (2012) Thermal Degradation of Rice Husks on a Pilot Plant Utilization of the Products as Adsorbents for Oil Spill Cleanup. Journal of Thermal Analysis \& Calorimetry, 110, 111-118. http://dx.doi.org/10.1007/s10973-012-2282-x

[17] Yavuz, M., Gode, F., Pehlivan, E., Ozmert, S. and Sharma, Y.C. (2008) An Economic Removal of $\mathrm{Cu}^{2+}$ and $\mathrm{Cr}^{3+}$ on the New Adsorbents: Pumice and Polyacrylonitrile/Pumice Composite. Chemical Engineering Journal, 137, 453-461. http://dx.doi.org/10.1016/j.cej.2007.04.030

[18] Sharma, Y.C., Uma, Upadhyay, S.N. and Weng, C.H. (2008) Studies on an Economically Viable Remediation of Chromium Rich Waters and Wastewaters by PTPS Fly Ash. Colloids \& Surfaces A: Physicochemical and Engineering Aspects, 317, 222-228. http://dx.doi.org/10.1016/j.colsurfa.2007.10.015

[19] Anirudhan, T.S. and Radhakrishnan, P.G. (2008) Thermodynamics and Kinetics of Adsorption of $\mathrm{Cu}$ (II) from Aqueous Solutions onto a New Cation Exchanger Derived from Tamarind Fruit Shell. The Journal of Chemical Thermodynam- 
ics, 40, 702-709. http://dx.doi.org/10.1016/j.jct.2007.10.005

[20] Wickramasinghe, S.R., Han, B.B., Zimbron, J., Shen, Z. and Karim, M.N. (2004) Arsenic Removal by Coagulation and Filtration: Comparison of Groundwaters from the United States and Bangladesh. Desalination, 169, 231-244. http://dx.doi.org/10.1016/S0011-9164(04)00530-2

Submit or recommend next manuscript to SCIRP and we will provide best service for you:

Accepting pre-submission inquiries through Email, Facebook, Linkedin, Twitter, etc A wide selection of journals (inclusive of 9 subjects, more than 200 journals)

Providing a 24-hour high-quality service

User-friendly online submission system

Fair and swift peer-review system

Efficient typesetting and proofreading procedure

Display of the result of downloads and visits, as well as the number of cited articles

Maximum dissemination of your research work

Submit your manuscript at: http://papersubmission.scirp.org/ 